\title{
FKBP5 Gene
}

National Cancer Institute

\section{Source}

National Cancer Institute. FKBP5 Gene. NCI Thesaurus. Code C105829.

This gene plays a role in protein folding. 